in the Russian market before and after crisis]. Financial Management, no. 1, pp. 13-25.

33. Zal'cman A.A. (2014) Osobennosti dividendnoj politiki rossijskih kompanij s kross-listingom [Dividend policy of cross-listed Russian companies]. Financial Research, vol. 45, no. 4, pp. 207-221.

\title{
CORPORATE GOVERNANCE AND EFFECTIVENESS OF A DIVERSIFIED COMPANY: RUSSIAN EXPERIENCE
}

\author{
Varvara Nazarova, \\ PhD in Economics, Researcher, Associate Professor, \\ National Research University Higher School of Economics, Russia \\ e-mailnvarvara@list.ru \\ Anzhelika Kolkina, \\ National Research University Higher School of Economics, Russia \\ e-mail lika.kolkina@yandex.ru
}

\begin{abstract}
Researchers come to controversial conclusions regarding the impact of corporate diversification on the company>s value and performance. The diversification strategy itself has been subject to strong criticism in the past 20-30 years. There is an opinion, however, that in emerging markets diversification has a positive impact on companies> value and effectiveness. Despite the existing advantages of diversified companies, planning and budgeting various business areas not related to each other is a considerably difficult task that results in the agency problem between managers and stakeholders. This leads to corporate governance problems in companies that use the diversification strategy.
\end{abstract}

Studying corporate governance in emerging countries is especially important, as they need to adjust their corporate governance standards to developed markets. The theory of corporate governance is now developing rapidly, especially in Russia, where researchers did not often turn to this subject. In the last decade, this issue has most often become a subject of research in China and India.

The issue of corporate governance in Russia is relevant today due to the fact that it is a mechanism of managing a company which makes it possible to balance the interests of managers and stakeholders. Moreover, companies are interested in attracting foreign investors, who pay significant attention to the level of current corporate governance. However, unlike in developed countries, corporate governance in developing capital markets is only being introduced. Today a lot of Russian companies are engaged in the optimisation of corporate governance largely to build a good reputation and do not pay enough attention to corporate governance principles, which a company should follow. Thus, today the low level of corporate governance is a problem in Russian companies, as the companies owners do not understand its significance. Moreover, the Russian business environment is rather specific and requires a certain approach in order to form an optimal corporate governance system. As far as research in this field is concerned, a positive impact of corporate governance on companies > effectiveness lacks empirical proof. A number of studies have not found a statistically significant positive correlation between the level of corporate governance in Russian companies and their effectiveness.

With regard to the stated issue, the purpose of this paper is to discover to what extent corporate governance has an impact on the effectiveness of Russian diversified companies. Such companies are a subject of particular interest, as not only developed and emerging economies have different features of corporate governance, but within one country there are also companies whose development strategy and industry have a significant impact on the optimal corporate governance structure. The study suggests the following hypothesis: the corporate governance system has a positive impact on the effectiveness of Russian diversified companies. 
The study has been conducted on a sample of Russian diversified companies with an original corporate governance index created for this purpose, which had never been done previously.

The study has a practical importance, because Russian diversified companies can use the corporate governance index devised during the study to assess their corporate governance level. Such procedure will make it possible to uncover the existing flaws and improve the corporate governance system in Russian companies. In their turn, the suggested methods and the resulting models of the correlation between market capitalisation, on the one hand, and fundamental factors and various factors of corporate governance, on the other, can be used in strategic planning and managing the value of diversified companies. In the paper, we also determine the impact of corporate governance on companies> performance, which enables us to suggest recommendations on enhancing the governance system in Russian companies.

Keywords: diversified company, corporate governance, emerging markets, economic value added, corporate governance index

JEL: G34, G39

\section{Introduction}

Researchers come to controversial conclusions regarding the impact of corporate diversification on the company's value and performance. The diversification strategy itself has been subject to strong criticism in the past 20-30 years. There is an opinion, however, that in emerging markets diversification has a positive impact on companies> value and effectiveness. Despite the existing advantages of diversified companies, planning and budgeting various business areas not related to each other is a considerably difficult task that results in the agency problem between managers and stakeholders. This leads to corporate governance problems in companies that use the diversification strategy.

Studying corporate governance in emerging countries is especially important, as they need to adjust their corporate governance standards to developed markets. The theory of corporate governance is now developing rapidly, especially in Russia, where researchers did not often turn to this subject. In the last decade, this issue has most often become a subject of research in China and India.

The issue of corporate governance in Russia is relevant today due to the fact that it is a mechanism of managing a company which makes it possible to balance the interests of managers and stakeholders. Moreover, companies are interested in attracting foreign investors, who pay significant attention to the level of current corporate governance. However, unlike in developed countries, corporate governance in developing capital markets is only being introduced. Today a lot of Russian companies are engaged in the optimisation of corporate governance largely to build a good reputation and do not pay enough attention to corporate governance principles, which a company should follow. Thus, today the low level of corporate governance is a problem in Russian companies, as the companies> owners do not understand its significance. Moreover, the Russian business environment is rather specific and requires a certain approach in order to form an optimal corporate governance system. As far as research in this field is concerned, a positive impact of corporate governance on companies > effectiveness lacks empirical proof. A number of studies have not found a statistically significant positive correlation between the level of corporate governance in Russian companies and their effectiveness.

With regard to the stated issue, the purpose of this paper is to discover to what extent corporate governance has an impact on the effectiveness of Russian diversified companies. Such companies are a subject of particular interest, as not only developed and emerging economies have different features of corporate governance, but within one country there are also companies whose development strategy and industry have a significant impact on the optimal corporate governance structure. The study suggests the following hypothesis: the corporate governance system has a positive impact on the effectiveness of Russian diversified companies.

The study has been conducted on a sample of Russian diversified companies with an original corporate governance index created for this purpose, which had never been done previously. 
The study has a practical importance, because Russian diversified companies can use the corporate governance index devised during the study to assess their corporate governance level. Such procedure will make it possible to uncover the existing flaws and improve the corporate governance system in Russian companies. In their turn, the suggested methods and the resulting models of the correlation between market capitalisation, on the one hand, and fundamental factors and various factors of corporate governance, on the other, can be used in strategic planning and managing the value of diversified companies. In the paper, we also determine the impact of corporate governance on companies> performance, which enables us to suggest recommendations on enhancing the governance system in Russian companies.

\section{Literature review}

\section{Corporate governance in diversified companies}

The concept of corporate governance has different interpretations regarding its use. At the moment, the agency problem predominates in interpreting corporate governance, and that is why the emphasis is put on the control and monitoring of the interest conflict between managers and stakeholders [Ivashkovskaya et al., 2013]. The conflict is to be resolved by the board of directors, who serve as a link between the company's stakeholders and managers. Thus, the key link of corporate governance is the board of directors and their working procedures, which underpins the definition of corporate governance suggested by I.V. Ivashkovskaya [Ivashkovskaya, 2010]. To ensure a high level of corporate governance the structure of the board of directors is of high importance, namely the number of independent directors, the proportion of executive and non-executive directors, the optimal size of the board, the division of responsibilities, their focus on the strategic effectiveness of the company, etc. [Bhagat and Black, 1999]. Despite the fact that the board is one of the most important mechanisms in the theory of corporate governance, there are other significant aspects, such as information disclosure, shareholders' rights, and corporate social responsibility.

The value of diversification is in creating an intersectoral structure in order to reduce the costs of searching for new focus areas and coordinating their development, thereby increasing the effect of using market opportunities. However, emerging markets have their own specifics. According to Yiu et al. [2005], a typical feature of emerging markets is large successful corporations operating in multiple unrelated sectors, which has a negative impact on the effectiveness of such companies. In the 1990s, large-scale privatisation in Russia resulted in a big number of corporate groups, each of which had the leading position in one of the sectors of Russian economy in various regions of the country. In contrast to independent companies, companies of this type are more complex in terms of management discipline in affiliated companies and their modernisation [Iwasaki, 2014]. According to Strange et al. (2009), business groups can be prone to the agency problem due to their pyramidal structures, which is intensified by shareholders with controlling interest managing the company in order to maximise their benefits rather than the benefits of all shareholders.

However, in their study, Lien, Li [2013] came to the conclusion that using the diversification strategy and not complying with certain rules of corporate governance can be a successful move in emerging markets in response to their institutional imperfections, therefore increasing the effectiveness of companies through the full use of all available resources. Moreover, the authors argue that developing countries are characterised by family corporations, which are interested in diversifying their businesses so as not to create competition between relatives within the same industry as well as to create a sustainable business for future generations. With regard to corporate governance, diversified family corporations are practically devoid of the agency problem, because all family members are interested in getting the maximum benefit, i.e. profit; however, the problem is that the proportion of independent directors is reduced to zero in such companies, since the owners do not trust outsiders.

Having analysed the articles on the diversification strategy in emerging and developed markets and the conclusions drawn by their authors, we believe it is important to highlight that the diversification strategy may result in significantly greater gains in emerging markets than in developed ones due 
to the aforementioned reasons. Anderson et al. [2000] have empirically proven that on average diversified companies have a higher proportion of independent directors on the board and the corporate governance structure systematically depends on the degree of diversification. Despite all the advantages of diversification in emerging markets, many companies go beyond the optimal level, which leads to the negative effects of diversification and results in the collapse of the company [Martin and Sayrak 2003]. Therefore, we have come to a conclusion that diversified and pure play companies have different features of corporate governance.

\section{Corporate governance in Russia}

There are differences in corporate governance in emerging and developed capital markets, as conditions of corporate governance development play an important role [Iwasaki, 2014]. Corporate governance in Russia is complex and differs significantly from corporate governance in developed countries for several reasons: limited development of the private financial sector, weakness of the institutional framework, concentrated ownership structure and strong state influence. According to A. Vernikov, Russian mentality does not distinguish between the concepts of management and ownership, which delays the transition of corporate governance in Russia to a new level [Stepanova, 2007]. The review Korporativnoye upravleniye i ustoychivoye razvitie biznesa: strategicheskie roli sovetov directorov [Corporate governance and business sustainability: The strategic role of the board of directors] notes that companies are mostly unwilling to disclose information about general shareholders' meetings on their websites [Pirogov and Zhivotova, 2007]. The authors also point out that only a small number of companies have a provision on the dividend policy. L. Ruzhanskaya [2010] in her study, which identifies the nature of the agency problem among a board of directors, concludes that currently major stakes of companies in the industrial sector are still state-owned. The author notes that state-owned companies more willingly comply with the standards of corporate governance, since the use of the corporate code is a mandatory element of their corporate strategy. It is quite unusual that, comparing corporate governance in Russia and Europe, I.V. Ivashkovskaya and A.N. Stepanova have empirically proven the significant positive correlation between a large proportion of shareholders directly involved in management and the effectiveness of the company, which is uncharacteristic for developed markets [Stepanova, 2007]. The Russian approach to corporate governance is based on the control model, which differs significantly from the market model [Gazin, 2003]. Thus, we can conclude that Russian companies strive to enhance corporate governance; however, they do not fully implement all its principles, which is exacerbated by imperfections of the institutional framework.

\section{Modern methods of assessing the impact of corporate governance on a company's effectiveness}

The quality of corporate governance is usually measured by a corporate governance index expressed by an aggregate figure which is obtained by assessing corporate governance on a rating scale. There is a variety of corporate governance ratings used to assess its quality. Developed markets usually use ratings devised by rating agencies. The following ratings are considered to have been the first ones: The Corporate Library (TCL), Institutional Shareholder Services (ISS), Governance Metrics International (GMI) and Standard\&Poor's [Ertugrul, Hedge, 2009]. Some of the most well-known corporate governance ratings include the ratings by Standard\&Poor's (S\&P): Corporate Governance Score, Transparency and Disclosure (T\&D), Governance, Accountability, Management, Metrics, Analysis (GAMMA) [Ivashkovskaya et al., 2013]. There are also national ratings by agencies such as Troika Dialog, Expert-RA, as well as ratings created by the Institute of Corporate Law and Governance and Bruncwick UBS Warburg, which stopped their rating activity in 2004 [Black et al., 2006].

Another approach to the full-scale assessment of corporate governance is based on devising original research ratings. This approach is used if there is a need to integrate features of corporate governance quality for specific purposes of a study; it is especially popular in emerging markets, which results from vivid differences between corporate governance in developed and developing countries. This is confirmed by a number of authors who also argue that general corporate governance ratings are 
not suitable for developing countries [Black et al., 2012; Sami et al., 2011]. The most famous study within this approach is by Gompers et al. [2003]. There is also a very extensive range of studies conducted by Sami et al. [2011], Black et al. [2006], Black et al. [2012], Munisi, Randoy [2013] and others.

As this study is based on a sample of Russian diversified companies, we have chosen the second approach to analyse their corporate governance level. This approach includes devising an original (created by the author) corporate governance index. Let us have a closer look at the studies which describe the impact of corporate governance on a company's performance and which use an original corporate governance index.

As far as developing countries are concerned, in particular Russia, most studies are based on identifying the impact of one feature of corporate governance on a company's performance. However, there is a small number of studies where the quality of corporate governance is expressed by an aggregate corporate governance index. Black et al. [2006] in their study examined the impact of corporate governance on a company's value expressed by the logarithm of Tobin's Q. To measure the level of corporate governance authors used the ratings created by rating agencies: Brunswick USD Warburg, Troika Dialog, S\&P Corporate Governance Score, S\&P T\&D, Expert-RA and the rating by the Institute of Corporate Law and Governance. Based on the aforementioned ratings, the authors constructed an aggregate corporate governance index. The index has a strong positive impact on the logarithm of Tobin's Q both in regression with the panel data and in the OLS regression. Having compared several ratings, the authors found out that the S\&P T\&D (Transparency and Disclosure Rating) rating had the strongest explanatory power regarding Tobin's $\mathrm{Q}$. The main conclusion of this study is that the level of corporate governance in a company has a strong impact on the value of the company.

Based on the aforementioned study, I.V. Ivashkovskaya et al. [2007] chose the transparency and disclosure rating S\&P T\&D as a proxy variable of the corporate governance quality and studied the correlation between this indicator and a company's performance in terms of economic profit. The results of the study were based on twenty-nine Russian companies included in this rating whose financial statements conformed with IFRS; they showed a statistically significant positive correlation between the S\&P T\&D rating and economic profit.

The Russian Institute of Directors and Corporate Finance Center, State University - Higher School of Economics have also conducted a joint study (Issledovaniye RID - Expert-RA 2010). It focused on the relation between a company>s effectiveness and the Expert-RA rating. As an indicator characterizing a company>s strategic effectiveness the authors used economic profit in the form of economic value added (EVA), like in the previous study. The study did not confirm its hypothesis and did not produce statistically significant results. The authors explained this conclusion by the fact that the work of the board of directors in Russian companies is not aimed at achieving strategic effectiveness.

Thus, our literature review demonstrates the relevance of the chosen topic and proves the need for this type of studies due to controversial results of empirical studies.

\section{Methods of the study}

\section{Creating an original corporate governance index}

At the initial stage of the study, we developed the structure of the corporate governance index for Russian diversified companies. The variables included in the index were determined through the methods of analysis, synthesis and comparison of empirical data. The chosen structure of the corporate governance index is based on the papers by the authors who study the issues of corporate governance in developing countries, including the work by Ananchotikul [2007], where the corporate governance index was created for companies in Thailand, as well as the works by Black et al. [2012] and Munisi, Randoy [2013], who developed indices for Brazil and South Africa, respectively. Besides, the work by Chen, Chen [2012] has played an important part; based on 22,366 companies (both pure play 
and diversified) the authors showed which corporate governance mechanisms a diversified company should have for a more effective allocation of investment resources and minimal losses from the diversification strategy. The authors also demonstrated significant differences between effective corporate governance mechanisms in pure play and diversified companies.

All the variables included in the index are dummy variables that take the value of 1 or 0.5 in case of good corporate governance and 0 otherwise. After that, these mechanisms were divided into corporate governance subindices, and the structure of the original index was determined; it is composed of four subindices: Composition and structure of the board of directors, Ownership structure, Shareholders' rights and Information disclosure (see Table 1).

Table 1

The structure of the original corporate governance index for Russian diversified companies

\begin{tabular}{|c|c|c|c|}
\hline Number & Feature of corporate governance & Calculation rule & $\begin{array}{l}\text { Max number } \\
\text { of points }\end{array}$ \\
\hline \multicolumn{3}{|c|}{ A. Subindex Composition and structure of the board of directors } & 6 \\
\hline a1 & Number of board members & 1 if $8<$ a1 $<13$, otherwise 0 & 1 \\
\hline $\mathrm{a} 2$ & Number of independent directors & $\begin{array}{c}1 \text { if a } 2>1 / 2 \text { of all board members, } \\
\text { otherwise } 0\end{array}$ & 1 \\
\hline a3 & Revision commission & 1 if a $3=$ yes, otherwise 0 & 1 \\
\hline a4 & Audit committee & 1 if a $4=$ yes, otherwise 0 & 1 \\
\hline a5 & Compensation committee & 1 if a $5=$ yes, otherwise 0 & 1 \\
\hline a6 & Corporate governance committee & 1 if a $6=$ yes, otherwise 0 & 1 \\
\hline \multicolumn{3}{|c|}{ B. Subindex Ownership structure } & 4 \\
\hline b1 & Shares in managers' possession & 1 if there are none, otherwise 0 & 1 \\
\hline b2 & Blocking minority stake & 1 if there is one, otherwise 0 & 1 \\
\hline b3 & Shares belonging to independent directors & 1 if there are any, otherwise 0 & 1 \\
\hline b4 & State-owned shares & 1 if there are any, otherwise 0 & 1 \\
\hline \multicolumn{3}{|c|}{ C. Subindex Shareholders' rights } & 4 \\
\hline $\mathrm{c} 1$ & Holding annual shareholders' meetings & 1 if $\mathrm{c} 1=$ yes, otherwise 0 & 1 \\
\hline c2 & Following the 'one share, one vote' principle & 1 if $\mathrm{c} 2=$ yes, otherwise 0 & 1 \\
\hline $\mathrm{c} 3$ & Dividend policy disclosure & 1 if $\mathrm{c} 3=$ yes, otherwise 0 & 0.5 if 1 \\
\hline $\mathrm{c} 4$ & Explanation of the dividend payout level & 1 if $\mathrm{c} 4=$ yes, otherwise 0 & 0.5 if 1 \\
\hline $\mathrm{c} 5$ & Opportunity of remote voting & 1 if $\mathrm{c} 5=$ yes, otherwise 0 & 1 \\
\hline \multicolumn{3}{|c|}{ D. Subindex Information disclosure } & 7 \\
\hline d1 & Disclosure of board members' attendance & 1 if $\mathrm{d} 1=$ yes, otherwise 0 & 1 \\
\hline $\mathrm{d} 2$ & Disclosure of board members' compensation & 1 if $\mathrm{d} 2=$ yes, otherwise 0 & 1 \\
\hline $\mathrm{d} 3$ & Financial statements conform with IFRS & 1 if $\mathrm{d} 3=$ yes, otherwise 0 & 1 \\
\hline $\mathrm{d} 4$ & $\begin{array}{l}\text { Disclosure of members of the revison } \\
\text { commission }\end{array}$ & 1 if $\mathrm{d} 4=$ yes, otherwise 0 & 1 \\
\hline $\mathrm{d} 5$ & Disclosure of members of the audit committee & 1 if $\mathrm{d} 5=$ yes, otherwise 0 & 1 \\
\hline d6 & The Big Four auditing company & 1 if $\mathrm{d} 6=$ yes, otherwise 0 & 1 \\
\hline d7 & Publishes annual reports & 1 if $\mathrm{d} 7=$ yes, otherwise 0 & 1 \\
\hline \multicolumn{3}{|c|}{ Total } & 21 \\
\hline
\end{tabular}

Compiled by the author

The maximum number of points obtained on the index scale is twenty-one. Features included in each subindex have the same weight. For instance, to calculate the Composition and structure of the board of directors subindex, which includes six features, we have added up the resulting score and then divided this number by the maximum score received by any of the companies within this subindex. Therefore, scores in each subindex range from 0 to 1 . If there were missing variables in the sample, we replaced them with the minimal score obtained by other companies within this feature. Since non-disclosure of information is a sign of poor corporate governance, the replacement of missing 
variables with the minimal ones could not lead to distortion of the results. To calculate the general level of corporate governance in a company, we need to add up all the subindices and then divide the result by the total number of subindices (four).

\section{Developing a model for an empirical analysis of the impact of corporate governance on diversified companies' effectiveness}

In order to conduct the regression analysis of how corporate governance influences companies' effectiveness we have determined several indicators used as dependent and independent variables in the model. Some authors use such economic indicators as profitability of total assets (ROA), return on equity (ROE) and return on sales (ROS) as indicators of companies' effectiveness. A number of other studies which assessed the impact of corporate governance on the value of a company used such figures as dynamics of market capitalization and Tobin's Q. A new direction for the Russian market is the use of the economic profit indicator, Residual Income. This approach is more preferable for the purposes of this study, as the strategic direction of the board of directors cannot be measured by standard accounting figures, since they do not reflect the business's investment risks and cannot be a part of a fair assessment [Ivashkovskaya et al., 2007]. Alternative approaches that were initially used were based on discounted cash flow or internal rate of return models. However, within these approaches a significant part of the company's value is based on post-forecast figures, which are especially difficult to calculate. Moreover, these figures are static.

Therefore, we have chosen economic value added (EVA) as an indicator to measure a company's performance. EVA has a number of advantages. First, this indicator is not static and it reflects a company's results during a certain period of time. Second, this indicator, unlike accounting ones, provides a fair assessment, as it takes into account all the costs of doing business, including actual and opportunity ones. Thus, this indicator makes it possible to compare profitability, brought by the company's capital, with opportunity costs of investing. Considering all costs makes it possible to correctly assess the fundamental value of the company, its growth being the ultimate goal of any corporate strategy. In addition, the use of such indicator as economic profit, as opposed to market capitalisation and Tobin's Q, eliminates the effect of macroeconomic and other external influences on a company [Ivashkovskaya et al., 2007].

This indicator is calculated as the difference between net operating profit after tax (NOPAT) and the costs of financing the capital invested in the company, taking into account special adjustments regarding income and capital, called equity equivalents in the EVA concept [Ivashkovskaya et al., 2010]

$E V A=$ NOPATee - WACC $x$ CEee

In case of relative indicators, the calculation formula is:

$E V A=(R O I C-W A C C) \times C E$,

NOPATee - adjusted Net Operating Profit after Tax;

WACC (Weighted Average Cost of Capital);

$C E$ (Capital Employed);

ROTC (Return on Total Capital).

In order to calculate the WACC, it is necessary to calculate the cost of equity, which we did using the capital asset pricing model (CAPM). To do this, we calculated risk-free interest rate, risk premium and beta coefficient. The borrowing cost was defined as the risk-free interest rate with the addition of default risk. To calculate this index, we used the parameters for beta coefficient and default spread calculation from http://www.damodaran.com. We chose the returns on rouble-denominated Russia 25075 5-year government bonds from http://www.cbonds.info/ru as the risk-free rate of return.

The original corporate governance index we had developed at the previous stage of our research was used as an indicator measuring the level of corporate governance. We shall call this indicator Russian Corporate Governance Index or RCGI in order to use it as an independent variable in the model. 
In addition to the independent variable, it was necessary to include additional control variables into the corporate governance ranking in order to avoid missing variables and, as a consequence, unreliable results. The list of control variables was based on the work of Ivashkovskaya et al. [2013].

First, we need to include a variable denoting a company's equity size expressed by the logarithm of total assets (Size). This variable should be included in the regression model for the following reasons. An increase in the size of a company leads to an increase in the costs of maintaining corporate governance and complicates the task of the board of directors regarding coordination of the company's activities. If the board is unable to cope with management coordination, corporate strategy effectiveness decreases, which results in higher risks, lower return on capital and cash flow destabilisation. Moreover, relatively small companies should strive to enhance corporate governance in order to gain access to the capital market and attract more investors.

Second, it is also necessary to include the business risk indicator (Risk), expressed in the fluctuations of the company's operating profit. This indicator was calculated as the absolute deviation of the annual value of earnings before interest, taxes, depreciation, and amortization (EBITDA) from its average value for the period under review

$$
R I S K=\left(E B I T D A_{i t}-\overline{E B I T D A}_{i}\right)^{2} / E_{\text {EBITDA }} .
$$

The regression model also includes the investment variable (Capex) and the revenue growth rate variable (Growth) which reflect the character of company's strategic decisions. We also introduced the capital structure variable (CS) in order to take financial risk into account. It is calculated as the ratio of long-term debt capital to stock capital. Thus, the basic model takes the following form:

$$
E V A_{i t}=\alpha+\beta_{1} \times R C G I_{i t}+\beta_{2} \times \text { Size }_{i t}+\beta_{3} \times \text { Risk }_{i t}+\beta_{4} \times \text { Capex }_{i t}+\beta_{5} \times \text { Growth }_{i t}+\beta_{6} \times C S_{i t}+\varepsilon_{i t},
$$

where:

$E V A_{i t}$ is economic value added of the $\mathrm{i}$-th company in the year $t ; R C G I_{i t}$ is corporate governance index assigned to company $\mathrm{i}$ in the year $\mathrm{t}$; Size $_{i t}$ is the capital size of the $\mathrm{i}$-th company in the year $t$; Capex $_{i t}$ is the investments of the i-th company in the year $t$; Growth ${ }_{i t}$ is the sales growth rate of the $\mathrm{i}$-th company in the year $\mathrm{t}$; $C S_{i t}$ is the capital structure of the $\mathrm{i}$-th company in the year $t$.

Having developed the evaluation model, we collected data for the years 2011 to 2013. This period was chosen because the year 2013 was relatively stable in Russia both politically and economically. During this period, the level of corporate governance in most Russian companies became relatively high and was not influenced by a large number of external factors.

Initially, we analysed one hundred thirty five Russian diversified companies with related or unrelated diversification strategy. We used their annual reports, analytical reports, statutes and other official documents in order to assess the level of corporate governance. The initial sample was reduced to only public and open joint-stock companies since corporate governance is only available for these two types of companies. Thus, only seventy eight companies were assessed in terms of their corporate governance level using the index we had developed. The SPARK database and companies' reports from their official websites were used to calculate independent variables for the period from 2011 to 2013.

\section{Empirical study results}

We assessed the level of corporate governance in seventy eight diversified companies in the period from 2011 to 2013 using the developed corporate governance index structure. The article presents data on eighteen companies who received both high and middle and even lower scores . This allows the reader to more clearly represent the structure of the index. The results of the analysis are illustrated by Table 2 . 
Assessment of the level of corporate governance in Russian diversified companies

\begin{tabular}{|c|c|c|c|c|c|c|c|c|c|c|c|c|c|c|c|c|c|c|c|c|c|c|c|}
\hline & \multicolumn{6}{|c|}{$\begin{array}{l}\text { Composition and structure } \\
\text { of the board of directors }\end{array}$} & \multicolumn{4}{|c|}{ Ownership structure } & \multicolumn{5}{|c|}{ Shareholders' rights } & \multicolumn{8}{|c|}{ Information disclosure } \\
\hline & a1 & $\mathrm{a} 2$ & a3 & a4 & a5 & $\mathrm{a} 6$ & $\mathrm{~b} 1$ & b2 & b3 & b4 & $c 1$ & $c 2$ & $c 3$ & $\mathrm{c} 4$ & $c 5$ & $\mathrm{~d} 1$ & $\mathrm{~d} 2$ & d3 & d4 & d5 & d6 & d7 & \\
\hline OJSC TAIF 2011 & 1 & 0 & 0 & 0 & 0 & 0 & 1 & 0 & 0 & 0 & 1 & 1 & 0 & 0.5 & 0 & 0 & 0 & 1 & 0 & 0 & 0 & 1 & \\
\hline OJSC TAIF 2012 & 1 & 0 & 0 & 0 & 0 & 0 & 1 & 0 & 0 & 0 & 1 & 1 & 0.5 & 0.5 & 1 & 0 & 0 & 1 & 0 & 0 & 0 & 1 & \\
\hline OJSC TAIF 2013 & 1 & 0 & 1 & 0 & 0 & 0 & 1 & 0 & 0 & 0 & 1 & 1 & 0.5 & 0.5 & 1 & 0 & 0 & 1 & 1 & 0 & 0 & 1 & \\
\hline OJSC Alliance Group 2011 & 0 & 0 & 0 & 0 & 0 & 0 & 1 & 0 & 0 & 0 & 1 & 1 & 0 & 0.5 & 0 & 0 & 1 & 0 & 1 & 0 & 0 & 1 & 1 \\
\hline OJSC Alliance Group 2012 & 0 & 0 & 0 & 0 & 0 & 0 & 1 & 0 & 0 & 0 & 1 & 1 & 0 & 0.5 & 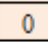 & 0 & 1 & 0 & 1 & 0 & 0 & 1 & 1 \\
\hline OJSC Alliance Group2013 & 0 & 0 & 0 & 0 & 0 & 0 & 0 & 0 & 0 & 0 & 1 & 1 & 0 & 0.5 & 0 & 0 & 1 & 0 & 1 & 0 & 0 & 1 & 1 \\
\hline OJSC Nefis Cosmetics 2011 & 0 & 0 & 0 & 0 & 0 & 0 & 0 & 0 & 0 & 0 & 0 & 0 & 0 & 0.5 & 0 & 0 & 1 & 0 & 0 & 0 & 0 & 1 & 1 \\
\hline OJSC Nefis Cosmetics 2012 & 0 & 0 & 0 & 0 & 0 & 0 & 0 & 0 & 0 & 0 & 0 & 0 & 0 & 0 & 0 & 0 & 0 & 0 & 0 & 0 & 0 & 0 & 0 \\
\hline OJSC Nefis Cosmetics2013 & 0 & 0 & 0 & 0 & 0 & 0 & 1 & 1 & 0 & 0 & 0 & 0 & 0 & 0.5 & 0 & 0 & 1 & 0 & 0 & 0 & 0 & 1 & 1 \\
\hline JSC HMS Group 2011 & 0 & 0 & 0 & 0 & 0 & 0 & 1 & 1 & 0 & 0 & 0 & 0 & 0 & 0.5 & 0 & 0 & 1 & 1 & 0 & 0 & 0 & 1 & 1 \\
\hline JSC HMS Group 2012 & 0 & 0 & 0 & 0 & 0 & 0 & 1 & 1 & 0 & 0 & 0 & 0 & 0 & 0.5 & 0 & 0 & 1 & 1 & 0 & 0 & 0 & 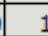 & 7 \\
\hline JSC HMS Group 2013 & 0 & 0 & 0 & 0 & 0 & 0 & 1 & 1 & 0 & 0 & 0 & 0 & 0 & 0.5 & 0 & 0 & 1 & 1 & 0 & 0 & 0 & & 1 \\
\hline OJSC Rostelecom 2011 & 1 & 0 & 1 & 1 & 1 & 1 & 0 & 0 & 1 & 1 & 1 & 1 & 0.5 & 0.5 & 1 & 0 & 1 & 1 & 1 & 1 & 1 & & 1 \\
\hline OJSC Rostelecom 2012 & 1 & 0 & 1 & 1 & 1 & 1 & 1 & 0 & 0 & 1 & 1 & 1 & 0.5 & 0.5 & 1 & 0 & 1 & 1 & 1 & 1 & 1 & & 1 \\
\hline OJSC Ros & 1 & 0 & 1 & 1 & 1 & 1 & 0 & 0 & 0 & 1 & 1 & 1 & 0.5 & 0.5 & 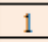 & 0 & 1 & 1 & 1 & 1 & 1 & & 1 \\
\hline OJSC Lukoil 2 & 1 & 1 & 1 & 1 & 1 & 0 & 0 & 0 & 0 & 0 & 1 & 0 & 0.5 & 0.5 & 0 & 1 & 1 & 1 & 0 & 1 & 1 & & 1 \\
\hline OJSC Lukoil 2012 & 1 & 1 & 1 & 1 & 1 & 0 & 0 & 0 & 0 & 0 & 1 & 0 & 0.5 & 0.5 & 0 & 1 & 1 & 1 & 0 & 1 & 1 & & 1 \\
\hline OJSC Lukoil 2013 & 1 & 1 & 1 & 1 & 1 & 0 & 0 & 0 & 1 & 0 & 1 & 0 & 0.5 & 0.5 & 0 & 1 & 1 & 1 & 1 & 1 & 1 & & 1 \\
\hline OJSC Rosseti 2011 & 0 & 0 & 1 & 1 & 1 & 0 & 0 & 1 & 0 & 1 & 1 & 1 & 0.5 & 0.5 & 0 & 0 & 1 & 1 & 1 & 1 & 1 & 1 & 1 \\
\hline OJSC Ros: & 0 & 0 & 1 & 1 & 1 & 0 & 0 & 1 & 1 & 1 & 1 & 1 & 0.5 & 0.5 & 0 & 0 & 1 & 1 & 1 & 1 & 1 & 1 & 1 \\
\hline OJSC Rosseti 2013 & 0 & 1 & 1 & 1 & 1 & 0 & 0 & 1 & 1 & 1 & 1 & 0 & 0.5 & 0.5 & 0 & 1 & 1 & 1 & 1 & 1 & 1 & & 1 \\
\hline OJSC UGMK 2011 & 0 & 0 & 1 & 0 & 0 & 0 & 0 & 1 & 0 & 0 & 1 & 0 & 0 & 0.5 & 0 & 0 & 0 & 0 & 0 & 0 & 0 & & 1 \\
\hline OJSC UGMK 2012 & 0 & 0 & 1 & 0 & 0 & 0 & 0 & 1 & 0 & 0 & 1 & 0 & 0 & 0.5 & 0 & 0 & 0 & 0 & 0 & 0 & 0 & & 1 \\
\hline OJSC UGMK 2-13 & 0 & 0 & 1 & 0 & 0 & 0 & 0 & 1 & 0 & 0 & 1 & 0 & 0 & 0.5 & 0 & 0 & 0 & 0 & 0 & 0 & 0 & & 1 \\
\hline OJSC Avtovaz 2011 & 1 & 0 & 1 & 1 & 1 & 0 & 0 & 1 & 0 & 1 & 1 & 1 & 0.5 & 0.5 & 0 & 0 & 1 & 1 & 0 & 0 & 1 & & 1 \\
\hline OJSC Avtovaz 2012 & 1 & 0 & 1 & 1 & 1 & 0 & 0 & 0 & 0 & 1 & 1 & 1 & 0.5 & 0.5 & 0 & 0 & 1 & 1 & 0 & 0 & 1 & & 1 \\
\hline OJSC Avtovaz 2013 & 1 & 0 & 1 & 1 & 1 & 0 & 0 & 1 & 0 & 1 & 1 & 1 & 0.5 & 0.5 & 0 & 0 & 1 & 1 & 0 & 0 & 1 & & 1 \\
\hline $\begin{array}{l}\text { OJSC North-Western } \\
\text { Shipping Company } 2011\end{array}$ & 1 & 0 & 1 & 0 & 0 & 0 & 1 & 1 & 0 & 0 & 1 & 1 & 0.5 & 0.5 & 0 & 0 & & 0 & 0 & & 0 & & \\
\hline $\begin{array}{l}\text { OJSC North-Western } \\
\text { Shipping Company } 2012\end{array}$ & 0 & 0 & 1 & 0 & 0 & 0 & 1 & 1 & 0 & 0 & 1 & 1 & 0.5 & 0 & 0 & 0 & 1 & 1 & of & 0 & 0 & & \\
\hline $\begin{array}{l}\text { OJSC North-Western } \\
\text { Shipping Company } 2013\end{array}$ & 0 & 0 & 1 & 0 & 0 & 0 & 1 & 1 & 0 & 0 & 1 & 1 & 0.5 & 0.5 & 0 & 0 & 1 & 1 & 0 & 0 & 1 & & 1 \\
\hline OJSC Mostotrest 2011 & 1 & 0 & 1 & 1 & 1 & 1 & 1 & 1 & 0 & 0 & 1 & 1 & 0.5 & 0 & 0 & 0 & 1 & 1 & 1 & 0 & 1 & & 1 \\
\hline OJSC Mostotrest 2012 & 1 & 0 & 1 & 1 & 1 & 1 & 1 & 0 & 0 & 0 & 1 & 1 & 0.5 & 0.5 & 0 & 0 & 1 & 1 & 1 & 1 & 1 & 1 & 1 \\
\hline OJSC Mostotrest 2013 & 1 & 0 & 1 & 1 & 1 & 1 & 1 & 1 & 0 & 0 & 1 & 1 & 0.5 & 0.5 & 0 & 1 & 1 & 1 & 1 & 1 & 1 & & 1 \\
\hline OJSC OMZ 2011 & 1 & 0 & 1 & 1 & 1 & 0 & 1 & 1 & 0 & 0 & 1 & 1 & 0.5 & 0.5 & 0 & 0 & 1 & 1 & 1 & 1 & 1 & & 1 \\
\hline OJSC OMZ 2012 & 1 & 0 & 1 & 1 & 1 & 0 & 1 & 0 & 0 & 0 & 1 & 1 & 0.5 & 0.5 & 0 & 0 & 1 & 1 & 1 & 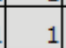 & 1 & & 1 \\
\hline OJS & 1 & 0 & 1 & 1 & 1 & 0 & 1 & 0 & 0 & 0 & 1 & 1 & 0.5 & 0.5 & 0 & 0 & 1 & 1 & 1 & 1 & 1 & & 1 \\
\hline OJSC Lenstroymaterialy 2011 & 0 & 0 & 0 & 0 & 0 & 0 & 0 & 1 & 0 & 0 & 1 & 0 & 0 & 0 & 0 & 0 & 0 & 0 & 0 & 0 & 0 & & 1 \\
\hline OJSC Lenstroymaterialy 2012 & 0 & 0 & 0 & 0 & 0 & 0 & 0 & 1 & 0 & 0 & 1 & 0 & 0 & 0 & 0 & 0 & 0 & 0 & 0 & 0 & 0 & & 1 \\
\hline OJSC Lenstroymaterialy 2013 & 0 & 0 & 0 & 0 & 0 & 0 & 0 & 1 & 0 & 0 & 1 & 0 & 0 & 1 & 0 & 0 & 0 & 0 & 0 & 0 & 0 & & 1 \\
\hline OJSC Severstal 2011 & 1 & 1 & 1 & 1 & 1 & 0 & 1 & 1 & 0 & 0 & 1 & 1 & 0 & 0 & 1 & 1 & 0 & 1 & 0 & 1 & 1 & 1 & 1 \\
\hline OJSC Severstal 2012 & 4 & 1 & 1 & 1 & 1 & 0 & 1 & 1 & 0 & 0 & 1 & 1 & 0 & & 1 & 1 & 0 & 1 & 1 & 1 & 1 & & 1 \\
\hline OJSC Severstal 2013 & 1 & 1 & 1 & 1 & 1 & 0 & 1 & 1 & 0 & 0 & 1 & 1 & 0 & 0.5 & 1 & 1 & 1 & 1 & 1 & 1 & 1 & & 1 \\
\hline OJS & 1 & 0 & 1 & 1 & 0 & 0 & 0 & 1 & 0 & 1 & 1 & 1 & 0.5 & 0.5 & 1 & 0 & 1 & 1 & 0 & 1 & 1 & 1 & 1 \\
\hline OJSC Gazprom 201 & 1 & 0 & 1 & 1 & 1 & 1 & 0 & 1 & 0 & 1 & 1 & 1 & 0.5 & 0.5 & 1 & 1 & 1 & 1 & 1 & 1 & 1 & & 1 \\
\hline OJSC Gazprom 2013 & \begin{tabular}{|l|}
1 \\
\end{tabular} & 0 & 1 & 1 & \begin{tabular}{|l|}
1 \\
\end{tabular} & 1 & 0 & 1 & 0 & 1 & 1 & 1 & 0.5 & 0.5 & 1 & to & 1 & 1 & 1 & $\frac{1}{1}$ & 1 & & 1 \\
\hline OJSC JSFC Sistema 201 & 1 & 0 & 1 & 1 & 1 & 1 & 0 & 1 & 1 & 0 & 1 & 1 & 0.5 & 0.5 & 1 & 1 & 1 & 1 & 1 & 0 & 1 & & 1 \\
\hline OJSC JSFC Sistema 2012 & 1 & 1 & 1 & 1 & 1 & 1 & 0 & 1 & 1 & 0 & 1 & 1 & 0.5 & 0.5 & 1 & 1 & 1 & 1 & 1 & 0 & 1 & & 1 \\
\hline OJSC JSFC Sisten & 1 & 1 & 1 & 1 & 1 & 1 & 0 & 1 & 1 & 0 & 1 & 1 & 0.5 & 0.5 & 1 & 1 & 1 & 1 & 1 & & 1 & & 1 \\
\hline OJSC Power Machines 201 & 1 & 0 & 1 & 1 & 0 & 0 & 1 & 1 & 0 & 0 & 1 & 1 & 0 & 0.5 & 1 & 0 & 1 & 1 & 1 & 1 & 1 & & 1 \\
\hline OJSC Power Machines 2012 & 1 & 0 & 1 & 1 & 0 & 0 & 1 & 1 & 0 & 0 & 1 & 1 & 0 & 0.5 & 1 & 0 & 1 & 1 & 1 & 1 & 1 & & 1 \\
\hline OJSC Power Machines 2013 & 1 & 0 & 1 & 1 & 0 & 0 & 1 & 1 & 0 & 0 & 1 & 1 & 0 & 0.5 & 1 & 0 & 1 & 1 & 1 & & 1 & & 1 \\
\hline OJSC.LSR Group 2011 & 1 & 0 & 1 & 1 & 1 & 0 & 0 & 1 & 0 & 0 & 1 & 1 & 0.5 & 0.5 & 0 & 0 & 1 & 1 & 0 & 1 & 1 & & 1 \\
\hline OJSC LSR Group 2012 & 1 & 0 & 1 & 1 & 1 & 0 & 0 & 1 & 0 & 0 & 1 & 1 & 0.5 & 0.5 & 0 & 0 & 1 & 1 & 0 & & 1 & & 1 \\
\hline OJSC LSR Group 2013 & 1 & 0 & 1 & 1 & 1 & 0 & 0 & 1 & 0 & 0 & 1 & 1 & 0.5 & 0.5 & 0 & + & 1 & 1 & of & & 1 & & 1 \\
\hline
\end{tabular}

After that, the obtained results were represented as a percentage value out of $100 \%$. OJSC JSFC Sistema received the highest corporate governance index for the year 2013. The resulting index value is $88.1 \%$ out of $100 \%$, which characterises this company as a diversified company with the best corporate governance in Russia. The highest average value for the period from 2011 to 2013 was also assigned to OJSC JSFC Sistema. OJSC Rostelecom and OJSC Gazprom hold the second place in this respect. The ranking of companies based on their level of corporate governance (highest to lowest) can be seen in the table below. 
Ranking of the corporate governance level in Russian diversified companies, average index value for 20112013, \%

\begin{tabular}{|c|c|c|}
\hline Place & Index value & Company \\
\hline 1 & 86.7 & OJSC JSFC Sistema \\
\hline 2 & 81.2 & OJSC Rostelecom \\
\hline 3 & 81.2 & OJSC Gazprom \\
\hline 4 & 79.8 & OJSC Severstal \\
\hline 5 & 75.4 & OJSC Rosseti \\
\hline 6 & 73.9 & OJSC Mostotrest \\
\hline 7 & 72.5 & OJSC Power Machines \\
\hline 8 & 68.0 & OJSC OMZ \\
\hline 9 & 63.6 & OJSC Avtovaz \\
\hline 10 & 61.6 & OJSC LSR Group \\
\hline 11 & 58.7 & OJSC Lukoil \\
\hline 12 & 50.8 & OJSC North-Western Shipping Company \\
\hline 13 & 44.1 & OJSC TAIF \\
\hline 14 & 34.7 & OJSC Alliance Group \\
\hline 15 & 30.5 & JSC HMS Group \\
\hline 16 & 25.4 & OJSC UGMK \\
\hline 17 & 20.2 & OJSC Lenstroymaterialy \\
\hline 18 & 6.9 & OJSC Nefis Cosmetics \\
\hline
\end{tabular}

Table 4 presents average corporate governance values (RCGI) over the three years. Comparing the average corporate governance values for the period from 2011 to 2013, it is important to note that during this period the average value in the aforementioned companies was on the increase. This indicates that the companies improved the level of corporate governance each year and strove to perfect it. In the period from 2011 to 2012 very little growth was registered; however, the average value increased by 3.8 percentage points in 2013 .

Table 4

Average values of corporate governance level in companies by year, \%

\begin{tabular}{|c|c|c|c|}
\hline Year & 2011 & 2012 & 2013 \\
\hline Average RCGI value & 56.1 & 56.7 & 59.9 \\
\hline
\end{tabular}

As to financial indicators, there is a negative trend in economic profit during the period in question. Data on the average value of economic profit for the period from 2011 to 2013 is presented in Table 5.

Table 5

Average Economic Value Added in 2011-2013, mln roubles

\begin{tabular}{|c|c|c|c|}
\hline & 2011 & 2012 & 2013 \\
\hline Average EVA & $20,276.4$ & $-29,870.4$ & $-1,891,116.1$ \\
\hline
\end{tabular}

This trend can be explained by the fact that in 2012 and 2013 many companies chose activities that could not provide a positive difference between ROIC and WACC, which indicates the low return on invested capital or investments. Maximum economic profit amounted to 515,100 mln 
roubles, received by OJSC Gazprom in 2011, while OJSC Rossetti received the minimum value of $-32,250,000 \mathrm{mln}$ roubles in 2013.

As for the other financial indicators, the Size index, expressed by the logarithm of a company's total assets, ranges from a minimum of 14 to 23. The Risk index describes the fluctuations in operating profit of the company, and its average value is $-84,321.1 \mathrm{mln}$ roubles. The standard deviation from the mean is 417,845.8 mln roubles, which indicates significant fluctuations in EBITDA in the period from 2011 to 2013. Capital expenditure in progress (Capex) also varies from 0 to 48,348.6 mln roubles. This parameter characterizes a company in terms of its strategic planning and decisionmaking. Companies with zero value of capital expenditure in progress are not focused on longterm planning; these companies account for 0.25 of all the companies under consideration. Revenue growth rate is, in general, positive, its average value being 1.64. OJSC LSR Group showed the highest growth rate in the period from 2011 to 2012.

Next, we tested the data for normality, multicollinearity and heteroscedasticity and built a basic regression model. The testing of possible specifications revealed that a linear model with no regard to years worked the best (see Table 6). The model has a relatively high determination coefficient (38\%); however, none of the variables included proved to be relevant at the significance level of 5\%.

Table 6

Alternative and basic models compared

\begin{tabular}{|c|c|c|c|c|}
\hline & \multicolumn{2}{|c|}{ Model 1} & \multicolumn{2}{|c|}{ Model 2} \\
\hline & Coefficient & Std. error & Coefficient & Std. error \\
\hline RCGI & $-5.21 \mathrm{e}+07$ & $6.89 \mathrm{e}+07$ & $-5.38 \mathrm{e}+07$ & $7.10 \mathrm{e}+07$ \\
\hline Size & $1.55 \mathrm{e}+07$ & $1.59 \mathrm{e}+07$ & $1.35 \mathrm{e}+07$ & $1.35 \mathrm{e}+07$ \\
\hline Risk & .1513891 & .1765611 & .1475784 & .1449205 \\
\hline Capex & -.6182231 & 1.064488 & & \\
\hline Growth & 4144837 & 6562289 & & \\
\hline year_2011 & & & $1.70 \mathrm{e}+07$ & $3.11 \mathrm{e}+07$ \\
\hline year_2012 & & & -3056405 & $1.60 \mathrm{e}+07$ \\
\hline Constant & $-2.44 \mathrm{e}+08$ & $2.38 \mathrm{e}+08$ & $-2.06 \mathrm{e}+08$ & $2.06 \mathrm{e}+08$ \\
\hline R-squared & .4479892 & & .4441021 & \\
\hline Namber of cases & 49 & & 50 & \\
\hline R-adj. & .3838019 & & .3809318 & \\
\hline AIC & 1927.155 & & 1965.58 & \\
\hline BIC & 1938.505 & & 1977.052 & \\
\hline$* \mathrm{p}<0.05, * *$ & 0.01 & & $\mathrm{p}<0.001$ & \\
\hline
\end{tabular}

The economic model of assessing corporate governance impact on the effectiveness of Russian diversified companies proved that the main hypothesis of our study (a positive correlation between corporate governance level and economic profit) should be rejected. This result was confirmed in the work by Ivashkovskaya [2010], where the rating compiled by RID - Expert-RA was employed as a measure of corporate governance level. This means that raising corporate governance level in a company does not increase its economic profit.

We may conclude that in most companies the activities of the board do not have a strategic direction, which is also indicated by negative values of a company's economic profit. Most Russian companies focus on the accounting profit in their analysis of financial and economic activities and do not take modern management concepts into consideration. However, the company being profitable in terms of accounting profit is not necessarily profitable in terms of economic profit, as the latter takes investment risks and all other costs into account, including actual and opportunity ones. According to Ivashkovskaya's article [2010], Russia was practically the only country where the analysis based on a company's value and cost management consulting services were hardly ever used. 
In this study, we chose economic profit as a dependent variable expressed by economic value added (EVA). According to the sample, economic profit value was negative in thirty-one of the fifty-one companies, which, consequently, rendered the average economic profit negative for the whole sample. This means that most companies use their own fixed and monetary assets ineffectively, so the costs exceed the profit received, and investments prove to be unprofitable as well, which is especially characteristic of diversified companies. The theoretical part of the paper rationalises that, for Russian companies, the diversification strategy at this stage is not a strategy that increases a company's value. The spread in EVA values was too big, as well. Thus, despite the increase in the level of corporate governance in most companies for the specified period of time, their economic profit value was negative, so there was no correlation between the level of corporate governance in a company and its economic value added.

According to the results, we can conclude that Russian companies need to improve their management systems and concepts, which will allow them to attract more foreign investors and, moreover, will improve both their business operations and investment activities. Furthermore, when using the diversification strategy, the concept of value becomes even more important, since it can prevent a company from entering unpromising industry sectors.

Since our model demonstrates the lack of correlation between the corporate governance index and economic profit value, we decided to narrow down the number of companies to those nineteen whose economic profit value was positive and to analyse the results.

The final regression model with a reduced sampling frame is:

Table 7

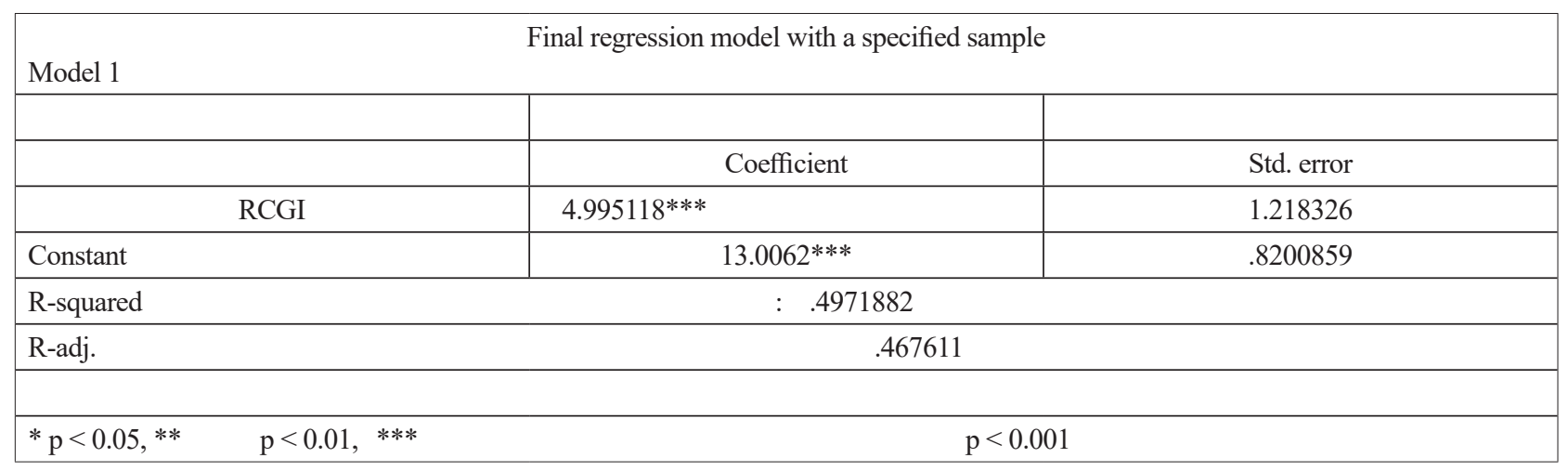

Thus, there is a statistically relevant positive correlation between independent and dependent variables. An increase of corporate governance index by 1 raises the company's economic value added by about $5 \%$. These results confirm our hypothesis that these variables are interrelated. The adjusted determination coefficient is $46.8 \%$, which is a high value even with the given sampling frame and with a single independent variable.

The estimated coefficients are unbiased, tenable and effective, as no problems with multicollinearity, heteroscedasticity and missing variables have been detected in the further analysis of the resulting model.

At the final stage of our study, we shall see which subindices have the greatest impact on a company's performance. To do this, we shall hold a series of econometric tests and alternately assign the weight of $100 \%$ to each subindex. The results are presented in Table 8 .

Table 8

The impact of individual corporate governance subindices on the effectiveness of companies

\begin{tabular}{|c|c|c|}
\hline RCGI subindex & Coefficient value & P-value \\
\hline Composition and structure of the board of directors & 3.656 & 0.000 \\
\hline Ownership structure & 4.462 & 0.011 \\
\hline Shareholders' rights & 4.275 & 0.000 \\
\hline Information disclosure & 3.869 & 0.003 \\
\hline
\end{tabular}


It is important to note that the Shareholders' rights subindex has the greatest influence on a company's performance, which indicates the importance of respecting the rights of shareholders, holding annual meetings and having a dividend policy. The Composition and structure of the board of directors and Information disclosure subindices hold the second place in terms of their importance. Ownership structure proved to be the least important subindex of all.

Thus, the regression analysis of nineteen observations based solely on companies with positive economic profit revealed that our hypothesis of a significant positive impact of corporate governance on the effectiveness of Russian diversified companies has been confirmed. We can therefore say that raising corporate governance level leads to the company's EVA growth as well.

\section{Conclusion}

The study suggests that enhancement of corporate governance mechanisms improves companies' performance. This confirms the fact that the analysis of corporate governance level is an important aspect of a company's financial architecture. Thus, the stated hypothesis about a positive impact that corporate governance has on the effectiveness of Russian diversified companies has been confirmed.

Companies should not only employ modern cost management concepts but also increase the level of corporate governance through the implementation of various committees on corporate governance and compensation, as well as follow the code of corporate governance with regard to information disclosure and shareholders' rights. Since the Shareholders' rights subindex has the greatest impact on improving a company's effectiveness, this feature of corporate governance should be treated with special attention.

We shall suggest several guidelines for the improvement of management concepts in Russian diversified companies in terms of corporate governance:

Assessment of corporate governance level should be an indispensable element in Russian diversified companies' management system.

It is necessary to improve corporate governance practices regarding shareholders' rights, as this aspect of corporate governance influences companies' effectiveness the most. Increasing the Shareholders' rights subindex by 1 raises economic value added by $4.28 \%$. That is, it is necessary to hold annual shareholders' meetings, facilitate remote voting and use the 'one share, one vote' principle. There is also a need for disclosure of a company's dividend policy, since $33 \%$ of all companies disclose their dividend policy and only $45 \%$ disclose the level of dividend payments.

It is necessary to improve corporate governance practices regarding the composition and structure of the board of directors, since increasing the Composition and structure of the board of directors subindex by 1 raises the economic value added by 3.66\%. Namely, it is necessary to create corporate governance, audit and compensation committees, as well as ensure the optimal ratio of independent directors to total number of the board members.

It is also necessary to observe corporate governance standards regarding information disclosure, since an increase in the Information disclosure subindex by 1 results in the growth of the economic value added by $3.87 \%$.

Moreover, more than half of the observations had a negative EVA value, which indicates that Russian companies need to improve their management concepts. Therefore, it would be reasonable to suggest the following recommendations:

It is necessary to shift from the analysis of standard accounting indicators to economic profit indicators by implementing a financial management system based on EVA assessment. This will improve both investment and business operations by identifying unpromising areas, as well as help to choose the best way to allocate resources.

We should introduce an integrated approach to the analysis of a company's operations, including the analysis of both financial indicators and qualitative characteristics of the company, such as corporate governance. It is proven by the fact that when the EVA values are negative, corporate governance is 
not as effective as when the aforementioned parameter has a positive value. Therefore, it is essential to analyse a company in terms of its financial architecture.

\section{References}

1. Ananchotikul N. (2007) Does Foreign Direct Investment Really Improve Corporate Governance? Evidence from Thailand. Working Paper. University of California, Berkley.

2. Anderson R., Bates T., Bizjak J. and Lemmon M. (2000) Corporate Governance and Firm Diversification. Financial Management, vol. 29, no. 1, pp. 5-22.

3. Bhagat S. and Black B. (1999) The uncertain relationship between board composition and firm performance. Business Lawyer, vol. 54, no. 3, pp. 921-963.

4. Black B., Gledson de Carvalho A. and Gorga E. (2012) What Matters and for which Firms for Corporate Governance in Emerging Markets? Evidence from Brazil (and other BRIC Countries). Journal of Corporate Finance, 18, 934-952.

5. Black B., Love I. and Rachinsky A. (2006) Corporate Governance Indices and Firms' Market Values: Time-Series Evidence from Russia. Emerging Markets Review, 7, 361-379.

6. Cbonds financial information agency official website. www.cbonds.ru. Accessed 28 April 2015.

7. Chen S. and Chen I. (2012) Corporate governance and capital allocations of diversified firms. Journal of Banking \& Finance, 36, 395-409.

8. Damodaran A. Official website. http//www.damodaran.com. Accessed 30 April 2015.

9. Ertugrul M. and Hedge S. (2009) Corporate Governance Ratings and Firm Performance. Financial Management, 38(1), 139-160.

10. Gazin G. (2003) Korporativnoe upravlenie v Rossii: realnoe konkurentnoe preimuschestvo. [Corporate government in Russia: Real competitive advantage.] Vestnik McKinsey, 1.

11. Gompers P., Ishii J. and Metrick A. (2003) Corporate Governance and Equity Prices. The Quarterly Journal of Economics, 118(1), 107-155.

12. Ivashkovskaya I.V. (2013) Finansovaya arkhitektura kompaniy. Sravnitelnye issledovaniya na razvitykh i razvivayuschikhsya rynkakh: monografiya. [Corporate financial architecture. Comparative studies in developed and emerging markets: monograph]. Ed. Ivashkovskaya, I.V., Stepanova, A.N., Kokoreva, M.S. Moscow: INFRA.

13. Ivashkovskaya I.V., Kukina E.B. and Penkina I.V. (2010) Ekonomicheskaya dobavlennaya stoimost. Kontseptsii. Podkhody. Instrumenty. [Economic value added. Concepts. Approaches. Instruments] . Journal of Corporate Finance Research, 2 (14), 103-108.

14. Ivashkovskaya I.V., Ponomareva M.O. and Settle, A.(2007) Deyatelnost sovetov direktorov i strategicheskaya effektivnost. [Activities of the board of directors and strategic effectiveness] .Problems of management theory and practice, no. 8.

15. Iwasaki I. (2014) Global Financial Crisis, Corporate Governance, and Firm Survival: The Russian Experience. Journal of Comparative Economics, vol. 42, no. 8, 178-211.

16. Lien Y. and Li S. (2013) Does Diversification Adds Firm Value in Emerging economies? Effect of Corporate Governance. Journal of business Research, vol. 66, no. 6, pp. 2425-2430.

17. Martin J. and Sayrak A. (2003). Corporate diversification and shareholder value: A survey of recent literature. Journal of Corporate Finance, vol. 9, no. 1, pp. 37-57.

18. Munisi G. and Randoy T. (2013) Corporate Governance and Company Performance across Sub-Saharan African Countries. Journal of Economic and Business, vol. 70, no. 10, pp. 92-110.

19. Pirogov N.K. and Zhivotova E.L. (2007) Review of reports delivered at the Second International Conference Korporativnoye upravleniye $\mathrm{i}$ ustoychivoye razvitie biznesa: strategicheskie roli sovetov directorov [Corporate governance and business sustainability: The strategic role of the board of directors] Section: Trends and problems in corporate governance development. Journal of Corporate Finance Research, no. 4, pp. 86-93. 
20. RID - Expert-RA research (2010) Report: Vliyanie kachestva korporativnogo upravleniya na effectivnost deyatelnosti kompanii. [The impact of corporate governance quality on a company's effectiveness]. Ed.Ivashkovskaya, I.V.

21. Ruzhanskaya L.S. (2010) Raskrytie informatsii rossiyskimi kompaniyami: rezultaty empiricheskogo issledovaniya. [Information disclosure by Russian companies: Empirical research results] . Russian Management Journal, vol. 8, no. 3, pp. 35-56.

22. Sami H., Wang J. and Zhou H. (2011) Corporate Governance and Operating Performance of Chinese Listed Firms. Journal of International Accounting, Auditing and Taxation, vol. 20, no. 8, pp. 106-114.

23. Stepanova A.N. (2007) Korporativnoe upravlenie i korporativnye resultaty: empiricheskie dokazatelstva na opyte stran s rastuschim rynkom kapitala. [Corporate governance and corporate results: Empirical proof from countries with growing capital market] . Journal of Corporate Finance Research, no. 4, pp. 65-75.

24. Strange R., Filatotchev I., Buck T. and Wright M. (2009) Corporate Governance and International Business. Management International Review, vol. 49, no. 4, pp. 395-407.

25. Yiu D., Bruton G.D. and Lu Y. (2005) Understanding business group performance in an emerging economy: Acquiring resources and capabilities in order to prosper. Journal of Management Studies, vol. 41, no. 1, pp. 183-206.

\title{
СТАНОВЛЕНИЕ И РАЗВИТИЕ ПРОЦЕССА КОНВЕРГЕНЦИИ ДВУХ ВИДОВ СТАНДАРТОВ: МСФО И US GAAР
}

\author{
Малофеева Татьяна Николаевна ${ }^{1}$,
}

Общеизвестно, что экономика - это фундамент, на котором стоит государство. И каким оно будет, зависит от характера экономических процессов, происходящих в стране. Одним из факторов благоприятного экономического климата является создание подходящих условий для возникновения и развития транснациональных корпораций (ТНК). Для плодотворной и выгодной работы ТНК необходимы стандарты, в соответствии с которыми компания, во-первых, ведет бухгалтерский учет, а во-вторых, предоставляет финансовую отчетность различным пользователям. Сложность в данном случае заключается, с одной стороны, в том, чтобы вести деятельность компании и предоставлять информацию о финансовых результатах компании в соответствии с принципами принимающих стран, т.е. стран, в которых расположена собственность ТНК; и, с другой стороны, в том, чтобы осуществлять те же действия - только в соответствии с принципами страны базирования, т.е. страны, в которой расположена штабквартира ТНК. В данной работе проводится анализ поэтапного становления и развития процесса конвергенции двух видов стандартов: американских общепринятых стандартов бухгалтерского учета (US GAAP) и международных стандартов финансовой отчетности (МСФО). Выявлено, что в различные периоды скорость конвергенции существенно изменялась, причиной чего являлась смена руководства администрации Белого дома. Определены слабые места МСФО и обоснована готовность мирового сообщества к высокой скорости глобализации.

Ключевые слова: МСФО, американские общепринятые принципы учета, конвергенция, сравнение, глобализация

JEL: M14; M40

\section{Введение}

Начиная с 1960-1970-х годов ученые стали задумываться над преобразованием мира в единую глобальную систему, и уже в 1990-х годах процесс глобализации стал весьма актуальным. Большинство стран стремится к созданию здоровой и устойчивой экономики, что связа-

\footnotetext{
${ }^{1}$ Преподаватель, НИУ «Высшая Школа Экономики» (119049, Россия, г. Москва, ул. Шаболовка, д.26; e-mail: malofeewa@mail.ru).
} 